\title{
Symbolism in Katherine Anne Porter's Novelettes
}

\author{
Wang Ru \\ Foreign Languages School \\ Jiangxi Normal University \\ Jiangxi Province, China
}

\begin{abstract}
Katherine Anne Porter is a famous American novelist in the 20th century. With superb writing skills and a unique literary style, she has become a recognized literary stylist in American literary circles. Porter is not a prolific writer, but her works are excellent, which gain the attention and praise of critics. Most of her works are related to her own life experiences and the real life, so literary critics have always defined her works as realism literature, but some of her works are rich in the features of modernism. This thesis taking Porter's famous novelettes Noon Wine and Pale Horse, Pale Rider as the research objects, discusses symbolism in her works, and strives to enrich readers' understanding of Porter's works. It is no longer limited to realism and understands the features of symbolism contained in Porter's works.
\end{abstract}

Keywords-Katherine Anne Porter; symbolism, Noon Wine, Pale Horse, Pale Rider

\section{Katherine AnNe Porter And Her Novelettes}

Katherine Anne Porter is not only an essayist, commentator, translator, but also an outstanding novelist. Some critics have said that Porter is a "writer's writer" [3] This is a very high compliment, which means that other writers can learn from her works. To have a good understanding of the implications behind Porter's works, Porter's 90-year life experiences are particularly concerned.

May 15, 1890, Katherine Anne Porter, a great writer, was born in Indian Creek, Texas, from a small farm in the South American family. She was brought up by her grandma who is a serious and eloquent elderly woman and influenced by her deeply.

Life in a monastery, for Porter, is stereotyped and repressed, so in 1906 Porter escaped from her home. In 1917, Porter started to be an editor in the Critics, mainly writing on the drama and social news. After that she has begun to write essays about musicals, plays. Porter liked traveling and toured between two cities Mexico and New York around 1930. Most of Porter's works were also created at this time. In 1922, Porter published his Virgo Maria Concepcion in Century Magazine. Over the next few years, three famous novel collections, The Flowering Judas, Pale Horse, Pale Rider and The Leaning Tower were published. In 1965, Porter merged the three collections, The Collected Stories of Katherine Anne Porter, which gave her the prize of Pulitzer Prize and the National Book Award in 1966, and the 1967 Gold Medal awarded by the American Academy of Arts. In 1961, Porter accomplished her unique novel, Ship of Fools in Boston and successfully published on April 1, 1962. The novel brought Porter popular reputation and long-awaited financial reward and it was filmed by Hollywood. Robert Payne Warren considered the novel as a "masterpiece" and "genius piece"[4]. Hendrick George, a literary critic, praised it as "a masterwork, a good, full of power that blends naturalism with symbolism”[5].

Not a high-yield writer, Porter published only 27 short stories, 6 novelettes and a long novel in her life. However, her attitude toward literary creation was especially serious and conscientious. Most of her works draw materials from her life experiences, like the most notably the Miranda series.

This essay selects a collection of Porter's novelettes, Pale Horse, Pale Rider, published in 1939, which includes Old Morality, Noon Wine and Pale Horse, Pale Rider with the same name to the title of the collection. This cycle has a feeling of echoes around the content. The protagonists of Old Morality and Pale Horse, Pale Rider are all named Miranda. As time went by, Miranda grew up. Miranda experienced the alienation from the southern family society, the threat of death, and eventually surpassed the death. The background of Noon Wine is the hometown of Porter's childhood. Porter looks at the life of ordinary people in southern society and shows readers the paradox of good and evil, law and morality.

\section{SyMBOLISM TECHNIQUE}

Symbolism can be defined as "the art of expressing ideas and emotions not by describing them directly, not by defining their overt comparisons with concrete images, but by suggesting what these ideas and emotions are and by recreating them in the mind of the reader through the use of unexplained symbols". The word symbol stems from the Greek word "symbolon", which "denotes an object cut in two pieces, constituting a sign of recognition when those who carry it (them) can assemble the two pieces"'[11].

Symbolism is one of the most important features of art in modernism literature. As one of the major schools in the modernism movement, symbolism is widely used in modernism literary works and it enriches the connotation and significance of literary works. Symbolism in the modernism movement is quite different from the traditional symbolism in terms of its form and meaning. In traditional symbolism, Symbol and Symbolized establish a clear, unitary and stable relationship, such as the red a symbol of passion, the rose a symbol of love.

Porter, like all other great writers who like to use symbols, was also a master of symbolism. Influenced by some modernism writers like Henry James who liked to use symbolism technique in his works, Porter also volunteered to 
add symbolism skill to her works and found that "a further unfolding of the deep world of the imagination” [9].

The 1940s was Porter's high-yielding period when she traveled in Paris. Paris was the cradle of the emergence and development of symbolism. Therefore, the works she created at this time are also full of symbolism. The short stories Porter published at this time include The Grave, Flowering Judas, The Fig Tree, and The Leaning Tower. The titles of these short stories are full of obvious symbolic meanings. The title of The Grave symbolizes the death theme, Flowering Judas symbolizes betrayal and The leaning Tower symbolizes the fall of unreliable government.

Most critics think the symbols in Porter's works are obvious and easy to discern. Some has classified the symbols in her works into several categories: nature and animal symbols in The Grave and Ship of Fools; religious symbols in Flowering Judas; archetypal symbols in Noon Wine. In order to emphasize the modernism colors symbolized by Porter's three novelettes, it will more focus on the analysis of symbols that are ambiguous and abstract, namely character symbols and image symbols.

\section{A. Character Symbols in Noon Wine}

In Noon Wine, Porter successfully characterized a number of characters. These typical characters have become profound symbols that convey special meanings. The Thompsons and Mr. Helton are the most symbolic meaning in the symbolic characters of the novel. There are two interesting sets of symbols in this novel. For the Thompson, Mr. Thompson looks strong but frail, and Mrs. Thompson looks vulnerable but inside strong. Porter cleverly used character symbols to represent their own personality traits. Mr. Thompson needed to find the sense of superiority, because he always felt inferior to his wife, both socially and morally. This sense of superiority, for Mr. Thompson, manifests as machismo. Like his stiff black beard, his way of holding his head, his bluster, and his need for taking a drink now and then, these movements or appearances are symbols of his machismo.

Mr. Thompson was a tough weather-beaten man with stiff black hair and a week's growth of black whiskers. He was a noisy proud man who held his neck so straight his whole face stood level with his Adam's apple, and the whiskers continued down his neck and disappeared into a black thatch under his open collar[10].

For him, mowing the lawns and feeding the chickens were all women who would do, so Mr. Thompson was unwilling to do these things on the farm, and would never figure out why Mr. Helton would like doing these chores. From time to time to drink wine is also a symbol of masculinity for him " 'I never took a dram in my life,' said Mr. Thompson, 'and what's more I never will, "[10]. Compared with Mr. Thompson, who looks strong and healthy, Mrs. Thompson appears delicate. This weakness is symbolized by weak and watering eyes. "Lying down, with the green shades drawn. She had a bowl of water by her on the table and a wet cloth over her eyes" [10].
Although Mrs. Thompson's image was extraordinary weak, but after Mr. Hatch was killed, she was not broken down as the readers thought. Instead, she confronted everything with bravery and did not confine herself to the punishment of the heart as her husband who chose to commit suicide.

There is another pair of interesting symbols in Noon Wine, which contrast with Mr. Thompson and Mr. Helton. In other words, everything of Mr. Helton symbolizes Mr. Thompson's ending. Readers have a impression on Mr. Helton in the novel: pale, slender, white eyes, his eyes staring at a place without trance. As mentioned earlier, at the beginning of the novel, $\mathrm{Mr}$. Thompson was ruddy with dark beard. But at the end, his appearance was exactly like Mr. Helton: 'Mr. Thompson's face, as he stood at the horse's head and began unhitching, was gray except for the dark blue of his freshly shaven jaws and chin, gray and blue and caved in, but patient, like a dead man's face” [10]. Not only appearances, but even habits are similar. Mr. Helton repeated the same harmonica song over and over again; Mr. Thompson later repeated the killings event. Even there is no audiences, he would tell himself again and again in his mind that he would be convinced that he is innocent; Mr. Helton killed his brother because of impulse. Similarly, Mr. Thompson also killed Mr. Hatch because of being in a hurry and caused a tragedy. He was innocent in the view of the law, but he could not escape the pressure of public opinion only to commit suicide.

The symbolic meaning in the novel often reveals to the theme of it. Noon Wine is a tragedy occurred in a small town in the southern America, and tells the story of the emotions and sorrows of the ordinary people. There is no clear line between good and evil, law and morality, nor is it just a word to make it clear. Mr. Thompson's choice of suicide symbolizes the evil of humanity. He is not guilty of law, but both his family and community neighbors think he is guilty. Therefore, his death was also related to the great environment of Southern society at that time. People only concerned themselves with what they wanted to see and did not care about the consequences. Porter's paradox of law and morality discussed here responds to the modernism humanity concept and reveals Porter's unusual and profound observation of modern life.

\section{B. Image Symbols in Pale Horse, Pale Rider}

Symbolism and imagism have a close relationship for a long time. Frey mentions in his Anatomy of Criticism that "symbolism is used in the sense of thematically significant imagery", and symbols "begin with images of actual things and work outward to ideas and propositions" [2]. Both Symbolism and Imagism are literary strategies that use metaphorical language. Porter's literary creations also have a large number of image symbols, because of the impact of these writers who tend to use metaphorical language.

According to Pound, image refers to "presenting a complex of intelligence and emotion in a moment"[6]. Image may be visible relating to the eye, olfactory (smell), tactile (touch), abstract (the intellect) and kinesthetic (to the sense of movement and bodily effort). Porter's works contain almost all types of images, and this paper focuses on epidemic image and war image in Pale Horse, Pale Rider, both of which reveals the themes of the novel and are relatively less discussed. 
show headache"[10]. However, with development of the novel, this headache is more and more intense and frequent. No matter where Miranda went, she was always haunted by the pain of epidemic. Her colleagues said it was "caused by germs" and seen as "a strange, thick, greasy-looking cloud”[10]. When her lover Adam returns from the camp where "men are dying like flies.” And they never saw "so many new funerals" on the street[10]. Miranda had not realized the seriousness of the epidemic until she was in a coma and lost the consciousness at the end.

The epidemic image, from Miranda's description, is like a plague, and some critics interpret it religiously as "a sign of God's wrath, and the Danse Macabre" [12]. Through the "crazy fever of the flu epidemic," Porter has "created the atmosphere of a haunting moment of crisis"[8]. In the broad sense of symbol, flu is not just a medical term, but a metaphorical term equivalent to the illness of society at war. A society at war must be full of despair and death. Because war always brings some bad things, people will inevitably produce such negative qualities as suspicion, distrust and hypocrisy. In addition, these qualities are just as the flu spread in the community.

\section{CONCLUSION}

Porter employs the artistic techniques different from the traditional novels which embodies the features of modernism literature in these two novelettes. In Noon Wine, by shifts of limited perspective, Porter allows readers to see the different facts from different people's eyes. Although this enriches the plot of the novel, it also increases the difficulty of readers reading. Just as from different people's perspectives, good and evil, law and morality whose judgment are not unified so that it creates a paradox theme. In Pale Horse, Pale Rider, Porter applies the stream of consciousness and symbolism techniques to portray Miranda's fear of death through war and epidemic images. Death is not abstract, but rather to the cruel war and terrible diseases, which are the psychological factors to Miranda's fearing death. Interior monologue and free association in the novel show Miranda's true thoughts to the readers. From her interior monologue, after the death of Adam she has not been sluggish and overwhelmed by the fear of death. Instead, she courageously chose to envisage the death, walk out of the shadow of death, and move toward a new life. Miranda finally understands that death cannot be avoided, which coincides with the concept of death philosophy in the modernism ideology.

Through the analysis of symbolism in Katherine Anne Porter's two novelettes, this paper enriches the scholars' comprehension of her stylistic style and deepens the readers' understanding of her works. Porter is very talented in literary creation, combining symbolism techniques with her own writing style. There are the themes of the alienation between man and man, man and society, of the paradox of good and evil, law and morality, and of the fearing and envisaging death that many people in modern life would care about. These also present Porter's perception and concern for the complex life of modern people. her seems that only a small part in Miranda's body, just “a burning 


\section{ACKNOWLEDGEMENT}

This paper is supported by the grant of the National Social Science Foundation[15BWW036].

\section{REFERENCES}

[1] Chadwick, C. Symbolism [M]. London: Methuen \& Co Ltd. 1971.

[2] Frey, N. Anatomy of Criticism [M]. Princeton: Princeton University Press. 1957.

[3] Gary, E. R. Death and Katherine Anne Porter a Reading of the Long Stories[C]. IEEE International Conference on Plasma Science. 2003:286-287.

[4] Givner, J. Katherine Anne Porter: a Life [M]. New York: Simon and Schuster. 1982.

[5] Hendrick, G. Katherine Anne Porter [M]. New York: Twayne Publisher. 1965.
[6] Lodge, D. The language of modernism fiction: Metaphor and metonymy [A]. In Malcolm.B. \& J. McFarlane (Eds.), Modernism [C]. New York: Penguin Books ltd.1976: 482-493.

[7] Lodwick, H. Katherine Anne Porter [J]. Sewanee Review 48, 1940: 206-216.

[8] Matthiessen. F.O. That true and Human World [J]. Accent from Accent 5 , Winter, 1945:121-123.

[9] Porter, K. A. Collected Essays and Occasional Writings of Katherine Anne Porter [M]. New York: Delacorte Press,1970.

[10] Porter, K A. The Collected Stories of Katherine Anne Porter[M]. HBJ, 1979.

[11] Rose, J. Symbolization, Representation and Communication[M]. London: Institute of Psychoanalysis. 2007.

[12] Youngblood, S. Structure and Imagery in Katherine Anne Porter's Pale Horse, Pale Rider [A]. Modern Fiction Studies. 